\title{
Characterization of carbohydrate fractions of cassava plant meal and its utilization
} by growing pigs

\author{
${ }^{1}$ Akinfala, E. O., ${ }^{1}$ Amusan, K. O. and ${ }^{2 *}$ Adeyemi, M. A.
}

${ }^{1}$ Department of Animal Sciences, Obafemi Awolowo University, Ile-Ife, Nigeria

${ }^{2}$ Department of Animal Production and Health, Ondo State University of Science and Technology, Okitipupa, Ondo State, Nigeria

*Corresponding email: ade_maxwell@yahoo.com; Tel: +234 7063055036

\begin{abstract}
This research was carried out to evaluate the carbohydrate fractions of Cassava Plant Meal (CPM) and its utilization by growing pigs. CPM was prepared from milled sun-dried unpeeled cassava tuber plus leaves plus tender stems mixed in ratio 2.5:1. The proximate and carbohydrate fractions of CPM were determined. The CPM was included in the diets of growing pigs to replace maize at $0 \%, 25 \%, 50 \%, 75 \%$ and $100 \%$ levels corresponding to T1, T2, T3, T4 and T5, respectively. Twenty growing crossbred (Large White x Hampshire) pigs $(10.0 \pm 0.5 \mathrm{Kg})$ were used for the growth trial which lasted eight weeks. The proximate composition showed that CPM had $9.77 \%$ crude protein, $5.35 \%$ crude fibre, $3.38 \%$ ether extract, $4.40 \%$ ash and $65.70 \%$ nitrogen free extract. The starch content of CPM was $1.91 \%$ while the non-starch polysaccharides were $22.32 \%$ for neutral detergent fibre, $10.96 \%$ for acid detergent fibre, $4.15 \%$ for lignin, $11.36 \%$ for hemicelluloses and $6.81 \%$ for cellulose. The final body weight, average daily gain and feed to gain ratio were higher in pigs fed all the $C P M$ diets $(p>0.05)$. However, daily feed intake of the pigs increased $(p<0.05)$ with increasing levels of CPM in the diets. It can be concluded based on the findings in this study that CPM was low in starch, higher in soluble non starch than insoluble non starch polysaccharide with proximate values similar to that of maize. Also, CPM could replace maize completely in the diets of growing pigs without any deleterious effects on the growth response. The inclusion of CPM to replace maize could also lead to reduction in feed cost per kilogram gain of growing pigs.
\end{abstract}

Keywords: cassava plant meal; maize; growing pigs; non-starch polysaccharide

\section{Introduction}

Over the last few decades, the use of alternative feed resources particularly dietary energy sources in the diets of pigs have gained relevance. This may be due to the increasing demand for animal protein intake by the teeming human population at affordable cost (Pond and Lei, 2001; Zijlstra and Betranena, 2009). The suitability of cassava meal as an acceptable alternative energy feedstuff in the diets of different classes of pigs have been widely researched (Sonaiya et al., 1982; Sarwat et al., 1988; Ravindran, 1990; Adesehinwa et al., 2016) although composite Cassava
Plant Meal (CPM) has been identified as a better alternative to cassava meal (Akinfala and Tewe, 2001).

Works by Akinfala and Tewe (2001); Akinfala et al. (2013) and Adeyemi and Akinfala (2018) have shown both the nutritive and cost-effective advantages of adding the under-utilized fractions (leaves and tender stems) of cassava to the diets of pigs. This combination was developed to attain a comparable minimum crude protein level $(10 \%)$ as maize. However, a major limitation preventing use of most alternative feedstuffs including CPM is the high crude fibre content mainly the 


\section{Characterization of carbohydrate fractions of cassava plant meal}

structural indigestible carbohydrate often designated as Non Starch Polysaccharide (NSP) (Pluske et al., 2001; Zijltra and Betranena, 2009; Choct, 2015).

The NSP covers a broad range of polysaccharide molecules most importantly the non-alpha glucan of the plant cell wall. Studies (Bach Knudsen and Jorgensen, 2001; Lindberg, 2014; Choct, 2015) have indicated that the nutritional implications of high intake of NSP such as cellulose, hemicellulose, pectin and lignin in feedstuffs produced deleterious effects on nutrient digestibility, voluntary feed intake, feed efficiency and growth performance of pigs.

Previous works (Akinfala and Tewe, 2001; 2004; Akinfala et al., 2013) on the utilization of CPM by growing pigs have produced conflicting results compared to maize-based diets. This may be due to the NSP fractions present in the CPM diets. The option to improve the nutritional value and utilization of CPM by growing pigs with the use of enzyme requires detailed description of its carbohydrate fractions. This research was undertaken to characterise the carbohydrate fractions of CPM and its effects on the performance of growing pigs.

\section{Materials and methods \\ Collection and preparation of test ingredients}

The cassava variety of Tropical Manihot Species (TMS) 30572 were purchased from a commercial farm within Obafemi Awolowo University Teaching and Research Farm, Ile-Ife while the cassava leaves were harvested from the plant stem and the tender stems were harvested at about $5 \mathrm{~cm}$ usually $6-7$ nodes from the top of the plant. Following the procedure of Akinfala et al. (2002) the fresh tubers (unpeeled tubers) were washed and chopped into small pieces, sun dried on a concrete floor for about $2-3$ days depending on the intensity of sunlight. Also, the fresh cassava leaves and tender stem were sun dried for about 2-3 days and 4-5 days, respectively after harvesting and were then milled separately using $0.3 \mathrm{~mm}$ mesh grinding machine. The cassava plant meal (CPM) was prepared by mixing dried unpeeled cassava tubers with the leaves and tender stems at the ratio of 2.5:1 of unpeeled tuber to leaves and tender stem while the ratio of leaves to tender stem was 5:1. These combinations were adapted from Akinfala etal. (2002).

\section{Experimental animals, management and} design

Twenty growing crossbred (Large White $\times$ Hampshire) pigs of average initial weight of $10.00 \pm 0.57$ were used for the experiment. There were four pigs per treatment and each served as replicate. Routine management practices were carried out on the animals on treatment basis. Feed and water were supplied ad libitum throughout the experimental duration. The experiment lasted eight weeks and the experimental design was completely randomized.

\section{Experimental diets}

Five experimental diets were formulated. Diet T1 was maize based and served as the control. Diets T2, T3, T4 and T5 had 25\%, $50 \%, 75 \%$ and $100 \%$ of maize in diet T1 replaced with cassava plant meal (CPM) as shown in Table 1. 
Akinfala, Amusan and Adeyemi

Table 1: Composition of experimental diets

\begin{tabular}{|c|c|c|c|c|c|}
\hline \multirow[t]{2}{*}{ Ingredients } & \multicolumn{5}{|c|}{ Diets } \\
\hline & T1 & $\mathbf{T 2}$ & T3 & T4 & T5 \\
\hline Maize & 45 & 33.75 & 22.50 & 11.25 & - \\
\hline Cassava plant meal & - & 11.25 & 22.50 & 33.75 & 45.00 \\
\hline Soybean meal & 8.00 & 8.00 & 8.00 & 8.00 & 8.00 \\
\hline Palm kernel cake & 25.00 & 25.00 & 25.00 & 25.00 & 25.00 \\
\hline Fish meal & 2.00 & 2.00 & 2.00 & 2.00 & 2.00 \\
\hline Bone meal & 1.50 & 1.50 & 1.50 & 1.50 & 1.50 \\
\hline Oyster shell & 3.00 & 3.00 & 3.00 & 3.00 & 3.00 \\
\hline *Premix (Vitamin-Mineral) & 0.25 & 0.25 & 0.25 & 0.25 & 0.25 \\
\hline Salt & 0.25 & 0.25 & 0.25 & 0.25 & 0.25 \\
\hline Total & 100.00 & 100.00 & 100.00 & 100.00 & 100.00 \\
\hline \multicolumn{6}{|l|}{ Calculated Analysis } \\
\hline *Metabolizable energy (Kcal/Kg) & 3210.03 & 3193.58 & 3135.29 & 3085.34 & 3001.50 \\
\hline Crude protein $(\%)$ & 20.55 & 20.44 & 20.33 & 20.22 & 20.10 \\
\hline Crude fibre $(\%)$ & 5.20 & 5.53 & 5.86 & 6.20 & 6.52 \\
\hline
\end{tabular}

Proximate, carbohydrate fractions and statistical analyses

The proximate analysis of CPM and diets was carried out following the procedure of AOAC (2005). The insoluble carbohydrate fractions of the cassava plant meal were analysed by methods outlined by Van Soest et al. (1991). All data obtained were analysed using Analysis of Variance (SAS
9.1) and means were separated using Duncan Multiple Range Test at 5\% level of significance.

\section{Results}

Results of proximate composition and carbohydrate fractions of Cassava Plant Meal (CPM) are summarized in Table 2.

Table 2: Proximate content and carbohydrate fractions of cassava plant meal (CPM)

\begin{tabular}{lc}
\hline Parameters (\%) & CPM \\
\hline Dry matter (DM) & 88.63 \\
Crude Protein (CP) & 9.77 \\
Crude Fibre (CF) & 5.38 \\
Ash & 4.40 \\
Ether Extract (EE) & 3.38 \\
Nitrogen Free Extract (NFE) & 65.70 \\
Starch & 1.91 \\
Non-starch & \\
Neutral detergent fibre & 22.32 \\
Acid detergent fibre & 10.96 \\
Lignin & 4.15 \\
Hemicellulose & 11.36 \\
Cellulose & 6.81 \\
Insoluble NSP & 10.96 \\
Soluble NSP & 11.36 \\
Total NSP & 22.32 \\
\hline \multicolumn{1}{c}{ CPM: Cassava plant meal }
\end{tabular}




\section{Characterization of carbohydrate fractions of cassava plant meal}

The proximate composition of experimental diets is shown in Table 3 . The crude protein content ranged from $18.98 \%$ to $20.41 \%$ with T5 having the highest and T1 had the lowest. Similar trend was found with crude fibre and ash contents of the experimental diets. Increasing levels of cassava plant meal in the diets produced increasing crude protein, fibre and ash contents across dietary treatments. However, the ether extract and nitrogen free extract decreased across dietary treatments with increased inclusion of cassava plant meal to replace maize in the diets. In either case, T5 had the least values for the ether extract $(4.97 \%)$ and nitrogen free extract $(52.26 \%)$ while $\mathrm{T} 1$ had the highest values (5.52\% and $56.42 \%$, respectively).

Table 3: Proximate composition of experimental diets

\begin{tabular}{lcccccc}
\hline Proximate composition (\%) & T1 & T2 & T3 & T4 & T5 & +SEM \\
\hline Dry matter (DM) & 94.00 & 93.89 & 93.33 & 93.22 & 92.53 & 0.37 \\
Crude Protein (CP) & 18.98 & 19.37 & 19.55 & 19.99 & 20.41 & 0.20 \\
Crude Fibre (CF) & 6.50 & 6.52 & 6.60 & 6.88 & 7.05 & 0.07 \\
Ash & 5.58 & 6.17 & 6.78 & 7.05 & 7.94 & 0.29 \\
Ether Extract (EE) & 5.52 & 5.36 & 5.25 & 5.10 & 4.97 & 0.11 \\
Nitrogen Free Extract (NFE) & 56.42 & 55.97 & 55.15 & 54.20 & 52.26 & 0.53 \\
\hline
\end{tabular}

There were no significant differences ( $p$ $>0.05)$ in the average daily weight gain, feed conversion efficiency and feed cost per kilogram of growing pigs fed graded levels of cassava plant meal (Table 4). Pigs on diet T5 had the highest daily gain $(0.32$ $\mathrm{Kg}$ ) while pigs on diets $\mathrm{T} 1$ and $\mathrm{T} 4$ had the least $(0.30 \mathrm{Kg})$. Pigs on $\mathrm{T} 3$ gave the best feed efficiency (2.52) while pigs on T2 and T5 had the least (2.70) feed conversion efficiency. Significant differences ( $p$
$<0.05)$ existed for the average daily feed intake, feed cost per kilogram weight gain and total cost of feeding across dietary treatments. Pigs on T5 had the highest average daily feed intake $(0.83 \mathrm{Kg})$ while pigs on maize diet (T1) which served as control had the least value $(0.74 \mathrm{Kg})$. Pigs on T5 gave the lowest cost of feeding per kilogram weight gain (N 223.00) while T2 had the highest value (N 245.97).

Table 4: Growth performance and cost benefit ratio of growing pigs fed experimental diets

\begin{tabular}{|c|c|c|c|c|c|c|}
\hline \multirow[b]{2}{*}{ Parameters } & \multicolumn{6}{|c|}{ Diets } \\
\hline & T1 & $\mathbf{T 2}$ & T3 & T4 & T5 & +SEM \\
\hline Initial weight (Kg) & 10.00 & 9.88 & 9.88 & 10.00 & 10.00 & 0.32 \\
\hline Final weight (Kg) & 26.88 & 27.00 & 27.50 & 27.00 & 28.00 & 0.89 \\
\hline Average daily weight gain (Kg) & 0.30 & 0.31 & 0.31 & 0.30 & 0.32 & 0.01 \\
\hline Average daily feed intake (Kg) & $0.74^{\mathrm{b}}$ & $0.79^{\mathrm{ab}}$ & $0.79^{\mathrm{ab}}$ & $0.80^{\mathrm{a}}$ & $0.83^{\mathrm{a}}$ & 0.01 \\
\hline Feed to gain ratio & 2.53 & 2.70 & 2.52 & 2.67 & 2.70 & 0.12 \\
\hline Feed cost/Kg ( & 93.80 & 91.10 & 88.17 & 85.50 & 82.55 & 2.23 \\
\hline Feed cost $/ \mathrm{Kg}$ weight gain & $237.31^{\mathrm{ab}}$ & $245.97^{\mathrm{a}}$ & $222.20^{\mathrm{c}}$ & $228.30^{\mathrm{bc}}$ & $223.00^{\mathrm{c}}$ & 3.22 \\
\hline Total cost of feeding ( & $5253^{\mathrm{a}}$ & $5102^{\mathrm{ab}}$ & $4938^{b c}$ & $4788^{\mathrm{bc}}$ & $4623^{c}$ & 80.60 \\
\hline
\end{tabular}

$(\square=$ Nigerian currency, Naira ) (1USD $=\square 350)$;

$\mathrm{a}, \mathrm{b}, \mathrm{c}, \mathrm{d}, \mathrm{e}$ means in the same row having different superscripts differ at $\mathrm{p}<0.05$;

SEM: Standard Error of Means 


\section{Akinfala,Amusan and Adeyemi}

\section{Discussion}

The higher values obtained for the proximate composition (crude protein and ash) of CPM compared to the values reported in earlier studies by Akinfala et al. (2011) may be due to standardization of cassava tender stem to a length of $5 \mathrm{~cm}$, usually 6-7 nodes, from the top of the plant. This length has been found to be lush and high in mineral. Similar studies (Akinfala et al., 2002; Khajarern and Khajarern 2007; Iheukwumere et al., 2008) have also shown that these cassava fractions (leaves and tender stems) are very rich in crude protein, fibre, ash and ether extract but low in energy. Lower values (4.72\% and $9.00 \%)$ have been previously reported (Akinfala $e t$ al., 2002; 2011) for crude fibre and protein contents of CPM and whole cassava plant meal, respectively. The variations observed in the values may be due to varietal differences, length and age at harvest of the different cassava components (tender stems and tubers).

The cassava plant meal used in this study had high contents of NSP with only very low starch content compared with the values reported in earlier studies by Akinfala et al. (2011) and Ogundeji (2018). The neutral detergent fibre (NDF) and lignin contents obtained in this study were lower compared to the values reported by Akinfala et al. (2011) and Ogundeji (2018) who characterized the nutrient contents of CPM for broiler and growing pig as well as laying birds, respectively. However, this study reported higher acid detergent fibre (ADF) fraction compared with the values obtained in the studies of Akinfala et al. (2011) while Ogundeji (2018) reported higher values of $44.54 \%$. The differences observed in the contents of NSP contained in these studies may be due to the incorporation of less lignified tender stems component into the CPM mix. Work by Adeoye et al. (2004) obtained higher value of $30.38 \%$ for the NDF of CPM. Again the differences in the reported values may be due to the cassava variety used, mixing ratio of the CPM and the length $(5 \mathrm{~cm}$ usually $6-7$ nodes from the top of the plant) at harvest of the cassava components which may have reduced the lignification. Also, CPM had high proportion of soluble fractions of NSP than the insoluble. The critical importance of soluble NSP as reported by Pluske et al. (2001) is a determinant of the nutritive value of feedstuffs for monogastrics. Soluble NSP have been found in studies by Ikegami et al. (1990); Classon and Bedford (1991) to contribute to increased digesta viscosity, bulk and viscosity of the intestinal contents as well as decrease the rate of diffusion of substrates and enzymes within the digestive tract thereby producing negative effects on nutrients digestibility.

The proximate components of the experimental diets increased with increasing inclusion of CPM. This may be due to the incorporation of nutrient-rich cassava fractions (leaves and tender stems) into the diets. The crude protein values fall within the range $(18.0 \%$ and $20.0 \%)$ recommended by Olomu (2011) and Aduku (2012). Similarly, the crude fibre and nitrogen free extract followed the trend reported by Akinfala et al. (2013) who found that increased inclusion of cassava meal in the diets of growing pigs increased the crude fibre contents of the diets while the nitrogen free extract decreased.

The non-significant difference $(p>0.05)$ in the values obtained for the average daily weight gain of pigs fed experimental diets despite the varying fibre levels may be attributed to the processing technique of particle reduction used to enhance the nutritional value of the diets. This was similar to observations by Mavronichalis et al. (2000); Kim et al. (2005); Brufau et al. (2006); Len et al. (2009) and de Lange et al. 


\section{Characterization of carbohydrate fractions of cassava plant meal}

(2010) in pigs fed locally available resources of high fibre content. The authors found that the processing techniques (pelleting, reduction of particle size and enzymes supplementation) enhanced its nutritional value and utilization as well as overcome the shortcomings of poor nutritive value due to high fibre content and of other components in the feed.

Also, the average daily feed intake increased significantly $(p<0.05)$ with increasing inclusion of fibre-rich proportion of cassava leaves and tender cassava stems present in the CPM mix. These cassava fractions have been identified to be low in energy as depicted by the decreasing NFE values in Table 3. This result supports the scientific evidence reported by Akinfala et al. (2002) that monogastric animals will eat more to satisfy their energy requirements. It also agreed with reports of Adesehinwa (2008) that pigs will increase their feed intake to compensate for decrease in energy and nutrient density of the diet. The significant $(p<0.05)$ reduction in cost of production (feed cost) with increasing levels of CPM may be due to the higher cost per kilogram of maize against CPM (N 130 versus N 69.45). Similar findings were reported by Akinfala (1997) and Adesehinwa et al. (2016) who fed cassava peel-based diets to growing pigs and found reduction in cost of production.

\section{Conclusion}

It can be concluded based on the findings in this study that CPM was low in starch, higher in soluble non starch than insoluble non starch polysaccharide with proximate values similar to that of maize. Also, CPM could replace maize completely in the diets of growing pigs without any deleterious effects on the growth response. The inclusion of CPM to replace maize could also lead to reduction in feed cost per kilogram gain of growing pigs.

\section{References}

Adeoye, A. A., Udoh, J. E., Ayelomi, M. V. and Akinfala E. O. 2004. Effect of Additives on Cassava Plant Meal Based Diet on the Performance Characteristics of Broiler Chicken. Journal of Social and Basic Sciences Research, 2: 11-14.

Adesehinwa, A. O. K. 2008. A review paper on Energy and protein requirements of pigs and the utilization of fibrous feedstuffs in Nigeria. African Journal of Biotechnology, 7(25): 4798-4806.

Adesehinwa, A. O. K., Samireddypalle, A., Fatufe, A. A., Ajayi, E., Boladuro, B., and Okike, I. 2016. High quality cassava peel fine mash as energy source for growing pigs: effects on growth performance, cot of production and blood parameters. Livestock Research for Rural Development 28 (11)

Adeyemi, M. A. and Akinfala, E. O. 2018. Growth Response of Growing Pigs to Diets Containing Graded Levels of Cassava Plant Meal, in: proceeding of the $23^{\text {rd }}$ Annual Conference on Development of a Resilient Livestock Industry for National Economic Growth, Ilorin, Nigeria, 9 -13 September, $426-428$.

Aduku, A. O. 2012. Animal Nutrition in the Tropics. Feeds and Feeding Pasture Management, Monogastric and Ruminant Nutrition. Pp. $31-32$.

Akinfala, E. O. 1997. Performance of growing diets containing varying levels of cassava peels and palm kernel cake. M.Sc. Thesis Department of Animal Science, University of Ibadan. Pp: $23-35$.

Akinfala, E. O., and Tewe, O. O. 2001. Utilization of whole cassava plant by 


\section{Akinfala,Amusan and Adeyemi}

growing pigs in the tropics. Livestock Research for Rural

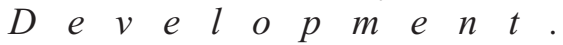
http:www.cipav.org.co/Irrd12.4akin .htm. 13(5).

Akinfala, E. O., Aderibigbe, A. O. and Matanmi, O. 2002. Evaluation of the nutritive value of $\quad \mathrm{w} \mathrm{hol} \mathrm{e}$ cassava plant meal as replacement for maize in the starter diets for broiler chickens. Livestock Research for Rural Development $\left.\begin{array}{llll}1 & 4 & (\end{array}\right)$ http:www.cipav.org.co/lrrd14.6akin .htm

Akinfala, E. O and Tewe, O. O. 2004. Supplemental effects of feed additives on the utilization of whole cassava plant by growing pigs in the tropics. Livestock Research for Rural Development. http://www.cipav.org.co/Irrdl6.2aki n.htm. 16 (10).

Akinfala, E. O., Matanmi, O. and Tinuala, J. A. 2011. Nutrient characterization of cassava plant meal and its utilization by broiler chickens in the tropics. Livestock Research for Rural Development. Volume 23, Article \#229. Retrieved December 9, 2018, from http://www.lrrd.org/lrrd23/11/akin2 3229.htm

Akinfala, E. O., Adegbaju, S. W. and Ilori, J. O. 2013. Evaluation of the nutritive value of whole cassava plant as a replacement for maize in the diets of growing pigs in the tropics. Ife Journal of Agriculture. 26:15-22.

AOAC (2005). Association of Official Analytical Chemist, Official Methods of Analysis $17^{\text {th }}$ edition, Washington D. C.

Bach Knudsen, K. E., and Jorgensen, H. 2001. Intestinal degradation of dietary carbohydrates from birth to maturity. In: Lindberg, J.E., Ogle, B. (Eds.), Digestive Physiology of Pigs. CABI Publishing, Oxon, UK, pp. $109-120$.

Brufau, J., Francesh, M., and PerezVendrell, A. M. 2006. The use of enzyme to improve cereal diets for animal feeding. J. Sci. Food Agric. 86:1705-1713.

Choct, M. (2015). Feed non-starch polysaccharides for monogastric animals: classification and function. Animal Production Science, DOI./10.1071/AN15276

de Lange, C. F. M., Pluske, J., Gong, J., and Nyachoti, C. M. 2010. Strategic use of feed ingredients and feed additives to stimulate gut health and development in young pigs. Livest Sci. 134:124-134.

Iheukwumere, F. C, Ndubuisi, E. C., Mazi, E. A. and Onyekwere, M. U. 2008. Performance, Nutrient Utilisation and Organ characteristics of broilers fed cassava leaf meal (Manihot esculenta Crantz), Pakistan Journal of Nutrition, 7 (1): $13-16$.

Ikegami, S., Tsuchihashi, F., Harada, H., Tsuchihashi, N., Nishide, E., and Innami, S. 1990. Effect of viscous indigestible polysaccharides on pancreatic biliary secretion and digestive organs in rats. Journal of Nutrition 120,353-206.

Khajarern, S., and Khajarern, J. 2007. Use of Cassava products in poultry feeding, Roots, Tubers, Plantains and Bananas in animal feeding. http://www.fao.org/DOCREP/003/T 0554E/T055 4E10.

Kim, J. C., Mullan, B. P., Pluske, J. R. 2005. A comparison of waxy versus non-waxy wheats in diets for weaner pigs: effects of particle size, enzyme 


\section{Characterization of carbohydrate fractions of cassava plant meal}

supplementation, and collection day on total tract apparent digestibility and pig performance. Anim. Feed Sci. Technol., 120:51-65.

Len, N. T., Ngoc, T. B., Ogle, B., and Lindberg, J. E. 2009. Ileal and total tract digestibility in local (Mong Cai) and exotic (Landrace $x$ Yorkshire) piglets fed low and high fibre diets, with or without enzyme supplementation. Livest. Sci. 126:73-79.

Lindberg, J. E. 2014. Fibre effects in nutrition and gut health in pigs. Journal of Animal Science and Biotechnology 5:15

Mavromichalis, I., Hancock, J. D., Senne, B. W., Gugle, T. L., Kennedy, G. A., Hines, R. H., and Wyatt, C. L. 2000. Enzyme supplementation and particle size of wheat in diets for nursery and finishing pigs. J. Anim. Sci., 78:3086-3095.

Ogundeji, S. T. 2018. Nutrient characterization of cassava plant meal and its utilization by growing pigs and laying birds. Ph.D. Thesis Department of Animal Science, Obafemi Awolowo University, Pp: $122-124$.

Olomu, J. M. 2011. Monogastric Animal Nutrition: Principles and Practice. Jachem Publication Benin, Nigeria, pp:20-150.

Pluske, J. R., Kim, J. C., McDonald, D. E., Pethick, D. W. and Hampson, D. J. 2001. Non-starch polysaccharides in the diets of young weaned piglets

Pond, W. G., and Lei, X. G. 2001. Of pigs and people. Pages 3-18 in Swine Nutrition, $2^{\text {nd }}$ ed. A. J. Lewis, and L. L. Southern, ed. CRC Press, Boca Raton, FL.

Ravindran. V. 1990. Feeding value and digestibility of cassava leaf meal for growing pigs. $\mathrm{Proc} . \mathrm{Fifth}$
Australasian. Animal production congress, 3:20-22.

Sarwat, V., Kakala, S. N. and Kategile, J. A. 1988. Performance of growingfinishing pigs fed diets containing fresh cassava leaves and roots. East Africa Agric. forestry Journal, 53: $111-115$.

SAS 2009. SAS User's Guide, version 9.1 for windows, Statistical Analysis Systems Institute, Inc.,Cary, NC, U.S.A.

Sonaiya, E. B., Omole, T. A., and Adegbola, A. A. 1982. Effects of cassava meal diets on the Performance and Carcass characteristics of Growing-finishing pigs. Nut Rep. Int'l., 26(3), 365-372.

Van Soest, P. J., Robertson, J. B. and Lewis. B. A. 1991. Methods for dietary fiber, neutral detergent fiber, and non-starch polysaccharides in relation to animal nutrition. Journal of Dairy Science, 74: 3583-3597.

Zijlstra, R. T. and Beltranena, E. 2009. Alternative feedstuffs in Swine Diets. Sustainable Swine Nutririon. First edition, (ed.) by Chiba, L. I. Published by John Wiley and Sons Inc.

Received: $14^{\text {th }}$ September, 2018 Accepted: $19^{\text {th }}$ December, 2018 